\title{
Systemowe reformy zdrowotne w Stanach Zjednoczonych. Obamacare versus Trumpcare
}

\author{
Katarzyna Badora-Musiał, Iwona Kowalska-Bobko, \\ Michał Zabdyr-Jamróz
}

Zakład Polityki Zdrowotnej i Zarządzania, Instytut Zdrowia Publicznego, Wydział Nauk o Zdrowiu, Uniwersytet Jagielloński Collegium Medicum, Kraków

Adres do korespondencji: Katarzyna Badora-Musiał, Zakład Polityki Zdrowotnej i Zarządzania, Instytut Zdrowia Publicznego, 31-531 Kraków, ul. Grzegórzecka 20, kasia.badora@uj.edu.pl

\section{Abstract}

\section{Systemic reform of health care in the United States. Obamacare versus Trumpcare}

The purpose of the article is to present the complexity of the US health insurance system and the changes it brings in Obamacare against the background of reform proposals pushed forward and run by the new US presidential administration (Trumpcare). An attempt will be made to compare the two reform proposals for the health care - Obamacare versus Trumpcare in the light of the assessment of the changes implemented by Barack Obama since 2013 as well as the political implications of the new proposals put forward by current President Trump.

The US health care system stakeholders environment is very divided in Obamacare's and President Trump's new proposals assessment. The new change is backed by insurance corporations. Meanwhile, the largest American medical association, the American Medical Association, has sent to the leaders of both parties in the Senate a statement stating that it supported Obamacare because it was a significant improvement over its previous status quo.

At this stage, presenting the whole formula of a new change is difficult due to unfinished legislative process.

Key words: Obamacare, Trumpcare, health system reform in USA, health care in USA

Stowa kluczowe: Obamacare, Trumpcare, reforma systemu zurowotneyo USA, ochrona zurowia w USA

\section{Wstęp}

System zdrowotny w Stanach Zjednoczonych jest dla Europejczyków niezrozumiały, zawiły i złożony. Dodatkowo uważany jest za mało efektywny, o czym świadczą rankingi międzynarodowe, na przykład WHO [1] już w 2000 roku umieściła USA na 37. miejscu wśród systemów ochrony zdrowia na świecie. Również wdrażane w tym systemie zmiany reformatorskie nie należą do przemyślanych, konsekwentnych czy spójnych. Raczej są wypadkową realizowanej doraźnej polityki oraz gry lobbingowej ważnych aktorów systemowych, takich jak prywatni ubezpieczyciele, firmy farmaceutyczne czy dostawcy usług zdrowotnych. Trudno oprzeć się wrażeniu, że większość podmiotów (graczy) amerykańskiego syste- mu zdrowotnego jest ciągle przekonana o konieczności zmian w tym zakresie. Każdy jednak ma inną wizję takiego nowego porządku, najlepiej bez naruszania własnych interesów.

O tym, że jest to trudna dziedzina do zmian w kierunku zapewniania powszechności i równości w dostępie do opieki medycznej, przekonał się już Bill Clinton, który próbował wprowadzić radykalne zmiany upublicznienia ubezpieczycieli i wdrożenia zasad powszechności i równości w dostępie do świadczeń zdrowotnych. Jego propozycja mimo początkowego poparcia społecznego natrafiła na silny opór korporacji ubezpieczeniowych, które podjęły masową i konsekwentną walkę medialną w obronie własnych interesów, przedstawiając projekt prezydenta jako naruszający fundamentalne zasady wolności, 
implikujący ogromne dodatkowe koszty pracy, właściwie antyspołeczny, a nawet antyamerykański [2]. Barack Obama nie popełnił błędu Billa Clintona i przy formułowaniu zasad swojej propozycji nie wkraczał w ogóle w kwestie własności ubezpieczycieli. Jak było jednak do przewidzenia, wymóg ubezpieczenia wszystkich, włącznie z osobami wysokiego ryzyka, znacznie podwyższył koszty ponoszone przez firmy ubezpieczeniowe. Zakładano, że zostaną one zrekompensowane dzięki uzyskaniu przez nie nowych klientów - zmuszonych do wykupywania polis. Tymczasem okazało się, że miliony Amerykanów, zwłaszcza młodych, wybrało opcję zapłacenia kar (w formie dodatkowych podatków), zamiast zakupu coraz droższych planów ubezpieczeniowych. W rezultacie Obamacare (właściwie Patient Protection and Affordable Care Act lub w skrócie ACA) zmniejszyła liczbę nieubezpieczonych tylko o około połowę. $Z$ powodu rosnących kosztów kilka wielkich firm ubezpieczeniowych, które początkowo uczestniczyły w federalnych giełdach, wycofało się, zmniejszając wybór oferowanych obywatelom niedrogich planów ubezpieczeniowych [3]. Te, które pozostały, podwyższyły składki albo zmniejszyły zakres refundacji usług. Donald Trump już w czasie kampanii wyborczej ostro krytykował reformę swojego poprzednika i zapowiadał wycofanie się z niej, podkreślając, że wbrew zapowiedziom dla wielu rodzin o średnich dochodach, które nie mogą z tego powodu liczyć na subwencje państwa, ubezpieczenia stały się za drogie.

Celem artykułu jest przedstawienie złożoności amerykańskiego systemu ubezpieczeń zdrowotnych oraz zmian, jakie wprowadza w nim Obamacare na tle propozycji reformatorskich forsowanych i procedowanych przez nową administrację prezydencką w USA. Podjęta zostanie próba porównania, zestawienia obu propozycji reformatorskich w ochronie zdrowia - Obamacare verus Trumpcare - na tle zarówno oceny implementowanych od 2013 roku zmian autorstwa Baracka Obamy, jak i politycznych uwarunkowań procedowania nowych propozycji w tym zakresie forsowanych przez obecnego prezydenta Trumpa.

\section{System ubezpieczen zulrowotnych w USA - sytuacja przed wprowadzeniem Obamacare}

Porównując wydatki (publiczne i prywatne), Stany Zjednoczone wydają więcej pieniędzy na opiekę zdrowotną niż jakikolwiek inny kraj (ponad 16,4\% PKB - jest to wartość prawie dwukrotnie wyższa niż średnia w Unii Europejskiej, która wynosi 8,9\%) [4]. Jednocześnie przed wprowadzeniem Obamacare w 2010 roku ponad 16\% Amerykanów [5] nie miało ubezpieczenia zdrowotnego, a wskaźniki, takie jak długość życia (78,7/OECD - 80,1) czy śmiertelność niemowląt $(6,1 / \mathrm{OECD}-4,1)$, były gorsze w porównaniu z pozostałymi krajami OECD [4, 6, 7], co wskazuje na wspomnianą już niską efektywność tego systemu.

W amerykańskim systemie zdrowotnym prywatni świadczeniodawcy odgrywają znacznie większą rolę niż w innych krajach o wysokim dochodzie. Sektor prywatny w Stanach Zjednoczonych rozwinął się bowiem już na początku lat 30. XX wieku, natomiast programy rządowe dla osób starszych i biednych - Medicare i Medicaid powstały dopiero w 1965 roku [8].

Milowe kroki reformatorskie w ochronie zdrowia w USA obrazuje Rysunek 1. Na szczególną uwagę zasługują zarówno działania w kierunku wdrożenia zasad zabezpieczenia społecznego podjęte jeszcze przed drugą wojną światową, jak i reformy wprost przeznaczone opiece zdrowotnej, idące w kierunku gwarancji dostępu do świadczeń zdrowotnych dla pewnych kategorii osób (starszych, ubogich, dzieci, kobiet). Obecnie po wdrożeniu Obamacare system zdrowotny w USA funkcjonuje zgodnie z zapisami Rysunku 2.

Przed wprowadzeniem reformy Obamy Amerykanie mogli mieć status: ubezpieczonych $\mathrm{w}$ ramach publicznego ubezpieczyciela, ubezpieczonych w ramach ubezpieczeń prywatnych lub nieubezpieczonych. Do podstawowych źródeł publicznego ubezpieczenia zdrowotnego należą: Medicare, Medicaid oraz CHIP, natomiast prywatne ubezpieczenia dzielą się na ubezpieczenia współ-

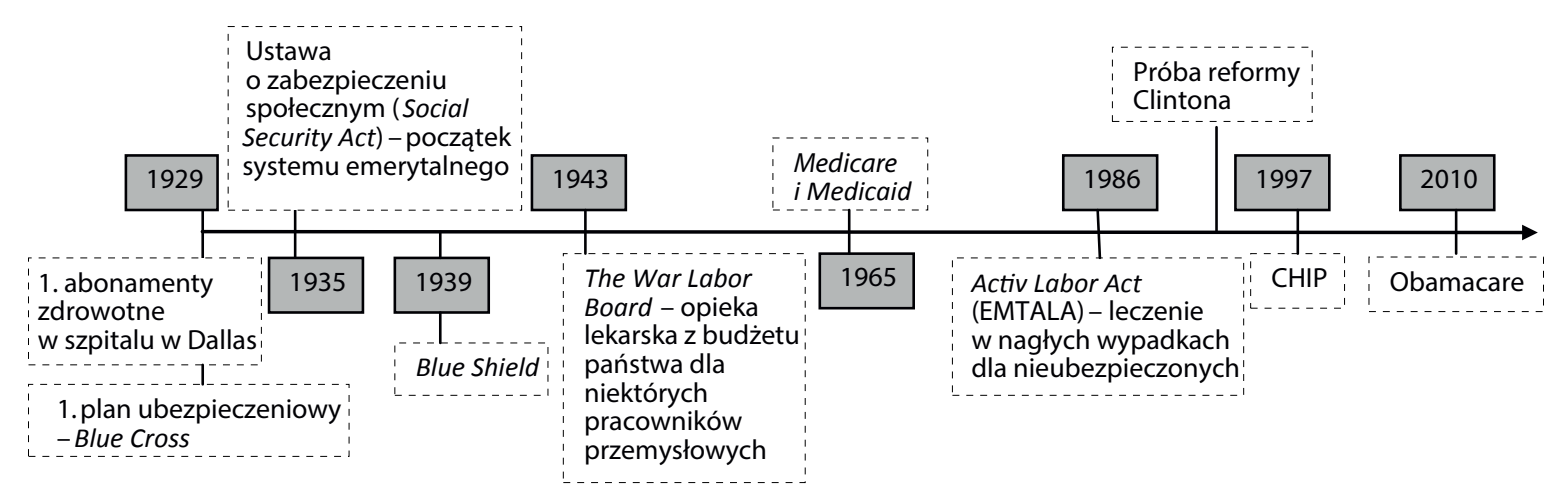

Rysunek 1. Historia reformy amerykańskiego systemu zdrowotnego.

Źródto: Opracowanie własne na podstawie Zabdyr-Jamróz M., Badora K., Reformy zdrowotne w USA z 2010 r. po orzeczeniu Sądu Najwyższego. Europeizacja Ameryki czy utrzymanie jej odrębności?, w: Namysty nad problemami polityki zdrowotnej globalnejeuropejskiej-krajowej: księga jubileuszowa prof. dra hab. Cezarego W. Włodarczyka, red. nauk. I. Kowalska, A. Mokrzycka, Difin, Warszawa 2013, s. 241-255 [8]. 


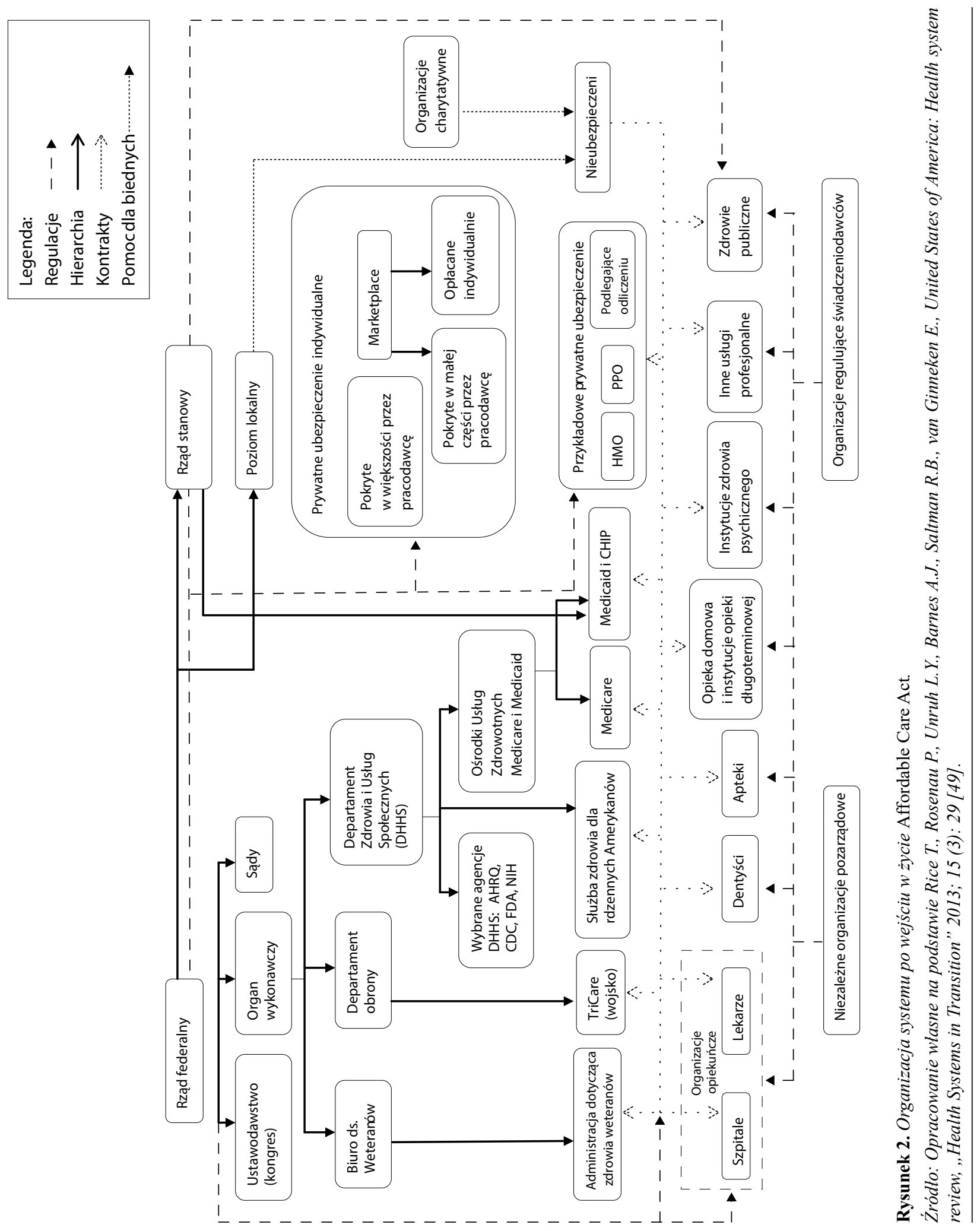


finansowane przez pracodawcę oraz ubezpieczenia indywidualne (opis poszczególnych źródeł opieki zdrowotnej przedstawia Tabela I).

W Stanach Zjednoczonych ubezpieczenie zdrowotne oferowane jest przez kilka tysięcy agencji ubezpieczeniowych. Proponują one różne plany ubezpieczeniowe o zróżnicowanym poziomie cen [9]. Wszystkie plany są opłacane składką, zazwyczaj miesięczną (tak zwaną premią). Większość $\mathrm{z}$ nich wymaga także opłaty $\mathrm{z}$ góry określonej kwoty za wizytę u lekarza (współpłacenie co-payment) lub ustalenia procentowego rozdziału wydatków na usługę medyczną pomiędzy pacjentem a firmą ubezpieczeniową (współubezpieczenie - co-insurance). Niektóre usługi wymagają obu powyższych opłat. Ponadto każdego roku większość osób musi zapłacić tak zwaną franszyzę redukcyjną (deductible), czyli pewną kwotę, zanim ubezpieczenie zacznie pokrywać koszty leczenia.

Większość prywatnych ubezpieczeń zdrowotnych jest w dużej części finansowana przez pracodawcę. W 2013 roku średnia roczna składka ubezpieczenia zdrowotnego dla osoby samotnej wyniosła 6029 USD, z czego pracodawca pokrywał kwotę 4948 USD, natomiast dla rodziny składka wynosiła 16351 USD, z czego pracodawca pokrywał 11786 USD. Przeciętna franszyza redukcyjna w 2013 roku wynosiła w tego typu planach 1135 USD, natomiast średnia kwota współpłacenia za przyjęcie do szpitala - 278 USD, a opłata za dzień w szpitalu - 264 USD [10]. Koszty tego typu ubezpieczeń w ciągu ostatnich 10 lat wzrosły prawie o $80 \%$ [11].

Pozostałe ubezpieczenia zdrowotne to ubezpieczenia indywidualne, wykupywane głównie przez: osoby samozatrudniające się, studentów, emerytów, którzy nie mogą jeszcze skorzystać z programu Medicare, ponieważ mają poniżej 65 lat, bezrobotnych, osoby zmieniające pracę, osoby zatrudnione w mniejszych firmach, w których pracodawca nie oferuje ubezpieczenia zdrowotnego [9]. Ten typ ubezpieczenia wykupuje niecałe $10 \%$ Amerykanów. Średni roczny koszt takiego ubezpieczenia w 2013 roku wyniósł 3319 USD dla osoby samotnej i 4230 USD dla rodziny. Do tego trzeba doliczyć jeszcze franszyzę redukcyjną, która wynosiła średnio przy polisie indywidualnej 3319 USD, natomiast przy rodzinnej - 4230 USD [12].

Więcej niż połowa Amerykanów korzysta ze świadczeń w ramach zintegrowanej opieki medycznej (managed care). Dla pacjenta oznacza to, że może on korzystać z szerokiego dostępu do świadczeń zdrowotnych, jeżeli zgodzi się na pewne ograniczenia w tym dostępie - na przykład będzie korzystał z usług medycznych tylko w ramach jednej sieci organizacji [9].

Do najbardziej popularnych planów zintegrowanej opieki medycznej w USA należą: HMO, PPO, EPO, POS (zob. Tabela II).

\section{Obamacare (ACA) - najważniejsze zapisy}

Najważniejszym rozwiązaniem wprowadzonym w Obamacare jest nałożenie „obowiązku” wykupienia ubezpieczenia zdrowotnego przez jednostki i przez firmy (powyżej 50 zatrudnionych) dla swoich pracowników. W wyniku orzeczenia Sądu Najwyższego jest to „obo- wiązek" tylko z nazwy, gdyż jego niedotrzymanie nie jest traktowane jak złamanie prawa, a jedynie jako przesłanka do nałożenia podatku (zwanego w ustawie „karą”). Dla sporej części Amerykanów (czyli ubezpieczonych przez pracodawcę) reforma systemu zdrowotnego nie przyniosła więc poważnych zmian. Dzięki Obamacare istniejące wcześniej plany zostały skorygowane o nowe regulacje, przynosząc dodatkowe przywileje, do których należą między innymi:

1) Zakaz odmowy ubezpieczenia ze względu na istniejące wcześniej problemy zdrowotne (pre-existing conditions). Składka ma być oparta bardziej na wieku i czynnikach geograficznych niż na płci i przede wszystkim historii medycznej ubezpieczonego [13].

2) Przedłużenie poszerzonego ubezpieczenia dla dorosłych dzieci w wieku do 26 lat.

3) Nakaz wyeliminowania rocznych lub dożywotnich limitów świadczeń.

4) Nakaz usunięcia dłuższych niż 90 dni okresów karencji (waiting period), czyli czasu, po którym polisa zostaje dopiero uruchomiona.

5) Zakaz zrywania umowy ubezpieczeniowej z wyjątkiem oszustwa lub celowego wprowadzenia w błąd odnośnie do sytuacji materialnej.

6) Nakaz pokrycia opieki prewencyjnej.

7) Zmniejszenie franszyzy redukcyjnej i współpłacenia. Od 2017 roku wydatki z własnej kieszeni (out of pocket) nie mogą przekroczyć 6650 USD dla osoby samotnej i 13300 USD dla rodziny [14].

Grupą, szczególnie dotkniętą przez zmiany, są kobiety. W ramach ubezpieczenia zdrowotnego rozszerzono pakiet usług medycznych związanych z kobiecym zdrowiem. Zaproponowano między innymi:

- zakaz odmowy sprzedaży ubezpieczenia kobiecie w ciąży, kobiecie ze zdiagnozowaną depresją lub doświadczającej przemocy domowej;

- wyrównanie cen ubezpieczenia dla kobiet i mężczyzn (w 2013 roku kobiety płaciły składkę na ubezpieczenie indywidualne średnio o prawie 400 USD wyższą) [12];

- pakiet działań prewencyjnych, takich jak mammografia, cytologia, szczepienia przeciwko HPV, testy alergiczne;

- sfinansowanie wszystkich form antykoncepcji w większości planów ubezpieczeniowych;

- rozszerzenie opieki położniczej poprzez wizyty prenatalne, badania przesiewowe, wypożyczanie laktatorów, konsultacje laktacyjne;

- pokrycie kosztów związanych z aborcją (w wielu prywatnych planach ubezpieczeniowych w zależności od stanów $\left.{ }^{1}\right)$

- wybór ginekologa/położnika jako lekarza podstawowej opieki zdrowotnej lub wizyty u ginekologa bez skierowania (w większości planów) [15].

Jak wspomniano, zmiany szczególnie dotknęły pracodawców, zachęcając i niejako zmuszając część z nich do ubezpieczania swoich pracowników. Pracodawca zatrudniający 50 lub więcej osób jest zobowiązany bowiem do ubezpieczenia minimum $95 \%$ pełnoetatowych pracowników [16]. Ubezpieczenie to musi spełniać standardy 


\begin{tabular}{|c|c|c|c|c|}
\hline Źródlo & Finansowanie & Uprawnieni & Zakres ubezpieczenia & $\begin{array}{c}\text { Liczba osób } \\
\text { w poszczególnych } \\
\text { źródlach (w mln) }\end{array}$ \\
\hline \multicolumn{4}{|c|}{ Medicare } & 47 \\
\hline $\begin{array}{l}\text { Część A } \\
\text { Hospital Ins- } \\
\text { urance }\end{array}$ & $\begin{array}{l}\text { Podatek od wyna- } \\
\text { grodzeń pracodawcy } \\
\text { i pracownika - po } \\
1,45 \% \text { każdy }\end{array}$ & \multirow{4}{*}{$\begin{array}{l}\text { Osoby } 65+\text {, niepełno- } \\
\text { sprawni, osoby cierpiące } \\
\text { na trwałą niewydolność } \\
\text { nerek wymagającą dializy } \\
\text { lub przeszczepu (ESRD) } \\
\text { lub stwardnienie zaniko- } \\
\text { we boczne (chorobę Lou } \\
\text { Gehriga) }\end{array}$} & $\begin{array}{l}\text { Pobyt w szpitalu (finansowane w } 100 \% \\
\text { do } 60 \text { dni), wykwalifikowana kadra } \\
\text { pielęgniarska w zakładzie opieki, opieka } \\
\text { w hospicjum, domowa opieka zdrowotna }\end{array}$ & 36 \\
\hline $\begin{array}{l}\text { Część B } \\
\text { Supplementary } \\
\text { Medical Ins- } \\
\text { urance }\end{array}$ & $\begin{array}{l}\text { Składki (standardowa } \\
\text { składka wynosiła 110,50 } \\
\text { USD/miesiąc) oraz } \\
\text { budżet federalny }\end{array}$ & & $\begin{array}{l}\text { Usługi medyczne (lekarzy i pielęgniarek), } \\
\text { badania laboratoryjne i diagnostyczne, } \\
\text { trwały sprzęt medyczny, niektóre usługi } \\
\text { profilaktyczne }\end{array}$ & 34 \\
\hline $\begin{array}{l}\text { Część C } \\
\text { Medicare } \\
\text { Advantage }\end{array}$ & $\begin{array}{l}\text { Budżet federalny } \\
\text { i składki }\end{array}$ & & $\begin{array}{l}\text { Alternatywa do części A i B (zapewnia } \\
\text { pokrycie tych samych usług, a także czę- } \\
\text { sto oferuje dodatkowe korzyści - badania } \\
\text { wzroku lub słuchu, opiekę dentystyczną). } \\
\text { Plany Medicare Advantage są to naj- } \\
\text { częściej plany HMO lub PPO oferowane } \\
\text { przez prywatne firmy ubezpieczeniowe }\end{array}$ & 11 \\
\hline Część D & $\begin{array}{l}\text { Składki, budżet fede- } \\
\text { ralny, budżet stanowy } \\
\text { z tytułu podwójnych } \\
\text { uprawnień }\end{array}$ & & Zakup leków RX (na receptę) & 27 \\
\hline Medicaid & $\begin{array}{l}\text { Budżet federalny oraz } \\
\text { budżety poszczególnych } \\
\text { stanów (po połowie) }\end{array}$ & $\begin{array}{l}\text { Różnie w zależności } \\
\text { od stanu, m.in. osoby } \\
\text { o niskich dochodach, } \\
\text { kobiety w ciąży, osoby } \\
\text { niepełnosprawne }\end{array}$ & $\begin{array}{l}\text { Usługi szpitalne i ambulatoryjne, opieka } \\
\text { prenatalna, leczenie chorób psychicznych } \\
\text { i uzależnień, opieka długoterminowa. } \\
\text { W zależności od stanów - opieka okuli- } \\
\text { styczna, stomatologiczna, leki RX }\end{array}$ & 48 \\
\hline $\begin{array}{l}\text { CHIP } \\
\text { Children Health } \\
\text { Insurance } \\
\text { Program }\end{array}$ & $\begin{array}{l}\text { Budżet federalny oraz } \\
\text { budżety poszczególnych } \\
\text { stanów, czasem składki } \\
\text { (nie mogą przekroczyć } \\
5 \% \text { dochodu rodziny) }\end{array}$ & $\begin{array}{l}\text { Dzieci z rodzin, w któ- } \\
\text { rych rodzice nie kwali- } \\
\text { fikują się do Medicaid, } \\
\text { ani też nie zapewniają } \\
\text { ubezpieczenia swoim } \\
\text { dzieciom w inny sposób } \\
\text { (np. poprzez programy } \\
\text { pracownicze) }\end{array}$ & $\begin{array}{l}\text { Różny w poszczególnych stanach, ale } \\
\text { wszędzie zapewniona jest kompleksowa } \\
\text { opieka, w tym: rutynowe badania kon- } \\
\text { trolne, szczepienia, wizyty u lekarza, } \\
\text { opieka szpitalna i ambulatoryjna, badania } \\
\text { diagnostyczne i laboratoryjne, opieka } \\
\text { stomatologiczna i okulistyczna, leki RX }\end{array}$ & 7,5 \\
\hline $\begin{array}{l}\text { Inne publiczne } \\
\text { źródła }\end{array}$ & Budżet federalny & $\begin{array}{l}\text { Głównie weterani }(V A) \\
\text { i pracownicy czynnej } \\
\text { służby wojskowej i ich } \\
\text { rodziny (TriCare), a także } \\
\text { rdzenni Amerykanie }\end{array}$ & $\begin{array}{l}\text { Usługi szpitalne i ambulatoryjne, leki RX, } \\
\text { opieka okulistyczna, laryngologiczna, } \\
\text { stomatologiczna }\end{array}$ & 4 \\
\hline \multicolumn{5}{|c|}{ Prywatne ubezpieczenia } \\
\hline $\begin{array}{l}\text { Finansowane } \\
\text { przez praco- } \\
\text { dawcę }\end{array}$ & $\begin{array}{l}\text { Składki odprowadzane } \\
\text { przez pracodawcę } \\
\text { i pracownika }\end{array}$ & $\begin{array}{l}\text { Zależy od wielkości } \\
\text { firmy, rodzaju stanowi- } \\
\text { ska, formy zatrudnienia, } \\
\text { pokrycia ubezpieczenia } \\
\text { małżonka lub dziecka }\end{array}$ & $\begin{array}{l}\text { Usługi szpitalne i ambulatoryjne, leki RX, } \\
\text { opieka okulistyczna, laryngologiczna, } \\
\text { stomatologiczna }\end{array}$ & 150 \\
\hline Indywidualne & Składki & - & $\begin{array}{l}\text { Usługi szpitalne i ambulatoryjne, leki RX, } \\
\text { opieka okulistyczna, laryngologiczna, } \\
\text { stomatologiczna }\end{array}$ & 15 \\
\hline Nieubezpieczeni & $\begin{array}{l}\text { Opłaty z własnej kiesze- } \\
\text { ni, pomoc organizacji } \\
\text { charytatywnych }\end{array}$ & - & - & 50 \\
\hline
\end{tabular}

Tabela I. Gtówne źródła opieki zdrowotnej w Stanach Zjednoczonych w 2010 roku.

Źródło: Opracowanie własne na podstawie Rice T., Rosenau P., Unruh L.Y., Barnes A.J., Saltman R.B., van Ginneken E., United States of America: Health system review, ,Health Systems in Transition” 2013; 15 (3): 1-431 [49]; KFF, Medicare a Primer 2010, The Henry J. Kaiser Family Foundation, April 2010, http://www.kff.org/medicare/upload/7615-03.pdf (dostęp: 10.07.2017) [50]; Baumgartner E., Emerytura polska i amerykańska ich taczenie i skutki Umowy o zabezpieczeniu społecznym, Polpress Services, Nowy Jork „Ameryka dla każdego” 2015, https://poradniksukces.com/wp/wp-content/uploads/2016/04/Emerytura_polska_i_am_ ebook_2015.pdf (dostep: 10.07.2017) [51]; CMS, Medicare Basics: A Guide for Families and Friends of People with Medicare, The Centers for Medicare and Medicaid Services Product No. 11034, 2014, https://www.medicare.gov/Pubs/pdf/11034.pdf (dostęp: 10.07.2017) [52]; CMS, Czym jest Medicare?, The Centers for Medicare and Medicaid Services Product No. 11306 - Polish, 2015, https://www.medicare.gov/pubs/pdf/other-languages-not-sp/Polish\%2011306-Medicare-Medicaid.pdf (dostep: 10.07.2017) [53]; CMS, Medicare and You 2017, The Centers for Medicare and Medicaid Services Product No. 10050, 2016, https://www. medicare.gov/pubs/pdf/10050-Medicare-and-You.pdf(dostęp: 10.07.2017) [54]; Snyder L., Rudowitz R., Ellis E., Roberts D., Medicaid Enrollment: June 2013 Data Snapshot, Kaiser Family Foundation, Washington, DC 2014, http://kff.org/medicaid/issue-brief/ medicaidenrollment-june-2013-data-snapshot/ (dostęp: 10.07.2017) [55]. 


\begin{tabular}{|c|c|c|c|c|}
\hline Rodzaj planu & $\begin{array}{l}\text { HMO - Health Mainte- } \\
\text { nance Organizations }\end{array}$ & $\begin{array}{l}\text { PPO - Preferred Provi- } \\
\text { der Organizations }\end{array}$ & $\begin{array}{c}\text { EPO - Exlusive Provider } \\
\text { Organizations }\end{array}$ & POS - Point-of-Service \\
\hline Opis planu & $\begin{array}{l}\text { Plan, który zakłada } \\
\text { leczenie w ramach sieci. } \\
\text { Wymaga od ubezpie- } \\
\text { czonego wyboru lekarza } \\
\text { pierwszego kontaktu, } \\
\text { który będzie kierował go } \\
\text { do specjalistów. Ubez- } \\
\text { pieczonemu zwracany } \\
\text { jest koszt za korzystanie } \\
\text { z usług w ramach sieci }\end{array}$ & $\begin{array}{l}\text { Plan, który łączy w sobie } \\
\text { cechy FFS (fee-for- } \\
\text {-service - opłata za } \\
\text { usługę) z HMO. Ubezpie- } \\
\text { czony może korzystać ze } \\
\text { świadczeń w ramach sieci } \\
\text { albo poza nią, zawsze } \\
\text { z obowiązkiem współ- } \\
\text { płacenia }\end{array}$ & $\begin{array}{l}\text { Plan, który zakłada } \\
\text { leczenie w ramach sieci. } \\
\text { Zazwyczaj świadczenio- } \\
\text { dawcy muszą podpisać } \\
\text { umowę o wyłączności, } \\
\text { czyli nie mogą wchodzić } \\
\text { w skład innych sieci }\end{array}$ & $\begin{array}{l}\text { Plan, który łączy w sobie } \\
\text { HMO i PPO. Ubezpieczo- } \\
\text { ny musi wybrać lekarza } \\
\text { pierwszego kontaktu, } \\
\text { a w razie wizyty u spe- } \\
\text { cjalisty potrzebuje dostać } \\
\text { od niego skierowanie, } \\
\text { może jednak korzystać } \\
\text { ze świadczeń także poza } \\
\text { siecią }\end{array}$ \\
\hline $\begin{array}{l}\text { Obowiązek wyboru leka- } \\
\text { rza podstawowej opieki } \\
\text { zdrowotnej }\end{array}$ & Tak & $\mathrm{Nie}$ & Tak & Tak \\
\hline $\begin{array}{l}\text { Wymóg skierowania do } \\
\text { specjalisty }\end{array}$ & Tak & $\mathrm{Nie}$ & $\mathrm{Nie}$ & Tak (z wyjątkami) \\
\hline $\begin{array}{l}\text { Możliwość leczenia poza } \\
\text { siecią }\end{array}$ & $\begin{array}{l}\text { Nie (z wyjątkiem przy- } \\
\text { padków nagłych) }\end{array}$ & $\begin{array}{l}\text { Tak, ale koszt takich usług } \\
\text { pokryty jest tylko czéścio- } \\
\text { wo przez ubezpieczyciela }\end{array}$ & $\begin{array}{l}\text { Nie (z wyjątkiem przy- } \\
\text { padków nagłych) }\end{array}$ & $\begin{array}{l}\text { Tak, ale koszt takich usług } \\
\text { pokryty jest tylko częścio- } \\
\text { wo przez ubezpieczyciela }\end{array}$ \\
\hline $\begin{array}{l}\text { Elastyczność korzystania } \\
\text { ze świadczeń }\end{array}$ & Mała & Najwyższa & Wysoka & Średnia \\
\hline Koszt & $\$$ & $\$ \$ \$ \$$ & $\$ \$ \$$ & $\$ \$$ \\
\hline
\end{tabular}

Tabela II. Popularne plany zintegrowanej opieki medycznej w Stanach Zjednoczonych.

Źródto: Opracowanie własne na podstawie eHalth, The Different Types of Health Insurance Plans, 2016, https://resources.ehealthinsurance.com/individual-and-family/different-types-health-insurance-plans (dostęp: 10.07.2017) [56]; CFF, The Insurance Basics, Cystic Fibrosis Foundation, https://www.cff.org/Assistance-Services/Insurance/Your-Insurance-Plan/The-Insurance-Basics/ (dostęp: 10.07.2017) [57]; ACS, Types of Health Insurance Plans, American Cancer Society, 2016, https://www.cancer.org/treatment/finding-and-paying-for-treatment/understanding-health-insurance/health-insurance-options/types-of-health-insurance-plans. html (dostęp: 10.07.2017) [58]; Makowska M., Czerw A., Reforma systemu ubezpieczeń zdrowotnych w Stanach Zjednoczonych. Zmiany wprowadzane przez Obamacare, ,Hygeia Public Health” 2014; 49 (4): 733-741 [9].

określone w ACA. W przeciwnym razie jest zobowiązany zapłacić „karę” w wysokości 2000 USD za każdego zatrudnionego (wyłączając pierwszych 30 pracowników). Z kolei pracodawcy zatrudniający 25 lub mniej pracowników o zarobkach rocznych średnio mniejszych niż 50000 USD są uprawnieni do ulg podatkowych na pokrycie ubezpieczenia swoim pracownikom [8].

Dodatkowo rozszerzony zostanie zakres osób objętych publicznym programem Medicaid przez podniesienie progu dochodowego uprawniającego do uczestnictwa. Od 2014 roku do programu Medicaid zgłaszać się mogą osoby o dochodach do $138 \%$ [17] federalnego poziomu ubóstwa (FPL), czyli nieprzekraczających 16000 USD. Zwiększenie dostępu nie dotyczy jednak wszystkich stanów. Zgodnie z decyzją Sądu Najwyższego, poszczególne stany mogą same decydować o takim rozszerzeniu [18]. Jednak aby sfinansować dodatkowe wydatki wynikające $\mathrm{z}$ przyjęcia nowych ubezpieczonych, w latach 2014-2016 rząd federalny pokrył w 100\% nakłady na te osoby, w 2017 roku sfinansuje 95\% wydatków z tego tytułu, w 2018 roku 94\%, w 2019 roku 93\%, a począwszy od 2020 roku - 90\% wydatków [19]. W porównaniu z rokiem 2013 programem Medicaid w 2015 roku zostało objętych o 12,3 miliona więcej osób [20].

Dla osób, które nie są ubezpieczone przez pracodawcę lub nie korzystają z programów publicznych, ustanowiono federalne i państwowe ,rynki” (Health Insurance
Marketplace), zwane także ,giełdami” ubezpieczeń zdrowotnych (health exchanges), gdzie różni ubezpieczyciele oferują swoje produkty osobom, a także małym firmom. Rynki te działają poprzez platformę internetowa ${ }^{2}$, dzięki której można wykupić ubezpieczenie, a także porównać oferty planów ubezpieczeniowych dostępnych w danym stanie. Wszystkie plany muszą oferować minimalny zakres świadczeń usług, między innymi:

- opiekę ambulatoryjną;

- opiekę szpitalną;

- opiekę nad kobietą w ciąży i noworodkiem;

- leczenie zaburzeń zdrowia psychicznego i uzależnień;

- leki na receptę;

- rehabilitację i urządzenia rehabilitacyjne;

- badania laboratoryjne;

- opiekę prewencyjną, program wellness ${ }^{3}$ i zarządzanie chorobami przewlekłymi;

- opiekę pediatryczną, w tym dentystyczną i okulistyczną.

Poszczególne usługi oferowane w ramach tych dziesięciu kategorii różnią się w zależności od planu, aby zapewnić elastyczność i różnorodność, która będzie odpowiadać potrzebom różnych osób. Wszystkie produkty ubezpieczeniowe oferowane na tej stronie są podzielone na cztery szczeble: brązowy, srebrny, złoty i platynowy. Plany zdrowotne różnią się jedynie finansowaniem kosztów usług zdrowotnych. Plan brązowy zakłada pokrycie 


\begin{tabular}{|l|l|l|l|}
\hline \multicolumn{1}{|c|}{ Nazwa planu } & \multicolumn{2}{|c|}{ Koszty } & \multicolumn{1}{c|}{ Najlepszy wybór dla: } \\
\hline \multirow{3}{*}{ Platynowy } & Miesięczna składka & $\$ \$ \$$ & \multirow{2}{*}{ osób, korzystających często z usług zdrowotnych } \\
\cline { 2 - 3 } & Koszt na wypadek choroby & $\$$ & \\
\hline \multirow{2}{*}{ Złoty } & Miesięczna składka & $\$ \$ \$$ & \multirow{2}{*}{ osób, które chcą zaoszczędzić na składkach przy zachowaniu dość niskich } \\
& Koszt na wypadek choroby & $\$ \$$ & osób, które chcą zbalansować opłaty na składki i wydatki z własnej kieszeni \\
\cline { 2 - 3 } & Miesięczna składka & $\$ \$$ & \multirow{2}{*}{ osób, które nie planują zbyt często korzystać z usług zdrowotnych } \\
\cline { 2 - 3 } & Koszt na wypadek choroby & $\$ \$ \$$ & \\
\hline \multirow{2}{*}{ Brązowy } & Miesięczna składka & $\$$ & \\
\cline { 2 - 3 } & Koszt na wypadek choroby & $\$ \$ \$ \$$ & \\
\hline
\end{tabular}

Tabela III. Porównanie poziomów planów ubezpieczeniowych.

Źródto: Opracowanie na podstawie Blue Cross and Blue Shield of Illinois, Understanding Health Insurance. Your Guide to the Affordable Care Act, https://www.bcbsil.com/pdf/standards/understanding_health_insurance_member_brochure.pdf (dostep: 10.07.2017) [59].

\begin{tabular}{|c|c|c|c|c|}
\hline & Brązowy & Srebrny & Zloty & Platynowy \\
\hline Maksymalny roczny wydatek OOP & \multicolumn{4}{|c|}{$6400 \$$} \\
\hline Franszyza redukcyjna & $5000 \$$ & $2000 \$$ & $0 \$$ & $0 \$$ \\
\hline Wizyta u lekarza pierwszego kontaktu & $60 \$$ & $45 \$$ & $30 \$$ & $20 \%$ \\
\hline Pobyt w szpitalu & $30 \%$ & $20 \%$ & $600 \$ /$ dzień & 250\$/dzień \\
\hline Nagły wypadek (ostry dyżur) & $300 \$$ & $250 \$$ & $250 \$$ & $150 \$$ \\
\hline Leki generyczne/preferowane marki & $25 \$$ & $25 \$$ & $25 \$$ & $5 \$$ \\
\hline Niektóre usługi zapobiegawcze & \multicolumn{4}{|c|}{ Brak podziału kosztów } \\
\hline
\end{tabular}

Tabela IV. Przyktad wydatków out of pocket $(O O P)$ w różnych planach przy ubezpieczeniu indywidualnym.

Źródto: Opracowanie na podstawie CAHP, 7 Ways the Affordable Care Act will Impact Individual Health Insurance, California Association of Health Plans, http://www.calhealthplans.org/pdfs/ACAImpactInfographicMultiplePages042913.pdf (dostep: 10.07.2017) [60]

$60 \%$ kosztów świadczeń, srebrny $70 \%$, złoty $80 \%$, natomiast $\mathrm{w}$ ramach platynowego planu pokrywane jest $90 \%$ kosztów świadczeń zdrowotnych objętych planem zdrowotnym [8, 19] (zob. Tabela III). Przeciętni konsumenci mają do wyboru 30 planów, w tym 14 planów srebrnych i 10 planów brązowych (jest to najpopularniejszy poziom wybierany przez 9 z 10 zarejestrowanych na rynku) [21]. Porównanie wydatków w różnych planach przedstawia Tabela IV.

Co ważne, tylko poprzez wykupienie ubezpieczenia na tej stronie możliwa jest pomoc federalna w postaci ulg podatkowych i dotacji. Taka ulga (Premium Insurance Tax Credits - PITCs) jest dostępna dla osób między 100 a 400\% federalnego poziomu ubóstwa (FPL) [22, 23]. Przykładowo, osoba samotna z rocznym dochodem pomiędzy 11500 USD a 46000 USD lub trzyosobowa rodzina $z$ dochodem pomiędzy 19500 USD a 78000 USD może uzyskać dofinansowanie do ubezpieczenia, jeżeli będzie ono kupione poprzez Marketplace (Healthcare.gov) [24]. W 2016 roku 8,5 miliona osób skorzystało z tej platformy w celu zakupu ubezpieczenia, z czego 83\% kwalifikowało się do otrzymania ulgi podatkowej. Średnia wysokość składki wynosiła 408 USD miesięcznie przed naliczeniem ulgi, która wynosiła 294 USD, ob- niżając wysokość składki do 113 USD miesięcznie (72\% redukcji składki) [13].

Od 2014 roku w przypadku niewykupienia ubezpieczenia zdrowotnego przez co najmniej trzy miesiące trzeba zapłacić karę, określaną w ACA jako ,płatność wspólnej odpowiedzialności" (shared responsibility payment), która jest $\mathrm{w}$ istocie podatkiem ${ }^{4}$. Od 2016 roku minimalna kara za brak ubezpieczenia wynosi 695 USD na osobę dorosłą i 347,50 USD na dziecko, przy czym maksymalna kara na rodzinę nie może być wyższa niż 2085 USD lub 2,5\% dochodu gospodarstwa domowego ${ }^{5}$.

$\mathrm{Z}$ indywidualnego obowiązku ubezpieczenia zdrowotnego wyłączone zostały następujące kategorie osób:

- osoby, które nie muszą składać zeznań podatkowych, ponieważ ich dochód jest niższy niż kwota, którą trzeba złożyć;

- osoby, które po uwzględnieniu wszelkich składek lub ulg podatkowych muszą zapłacić ponad 8,05\% swojego rocznego dochodu w celu uzyskania ubezpieczenia zdrowotnego;

- osoby, które kwalifikowałyby się do rozszerzonego zakresu programu Medicaid, ale stan, w którym mieszkają nie rozszerzył tych uprawnień;

- członkowie federalnie uznanego plemienia Indian; 
- członkowie uznanej sekty religijnej, która sprzeciwia się ubezpieczeniom zdrowotnym;

- osoby przebywające w więzieniu [22].

Pomimo kar za brak ubezpieczenia nadal wielu Amerykanów go nie posiada. W 2016 roku poziom średniej składki wzrósł w większości stanów, tylko w jednym (Missisipi) wystąpiła niewielka obniżka. Badanie The Kaiser Family Fundation z 2014 roku, przeprowadzone wśród osób nieposiadających ubezpieczenia, pokazało, że przyczyną niewykupienia polisy dla $48 \%$ jest właśnie wysokość składek [13].

\section{Kontekst polityczny wdrażanych zmian w ochronie zurowia W USA}

Liderzy aktualnie rządzącej w USA Partii Republikańskiej wielokrotnie zapowiadali, że są zdeterminowani, by anulować reformy zdrowotne wprowadzone przez Partię Demokratyczną pod przywództwem Baracka Obamy. Podczas kampanii wyborczej Donald Trump zapowiadał likwidację Obamacare, jednakże insynuując nie tyle zniesienie wielu prosocjalnych elementów systemu, ile wręcz ich rozszerzenie [25]. Później jednak jego stanowisko w tej sprawie bardziej dopasowało się do dominującej linii programowej republikanów, to jest zniesienia Obamacare w celu ograniczenia opodatkowania i zmniejszenia wydatków [26].

Najistotniejszym dla republikanów celem w odniesieniu do Obamacare jest likwidacja obowiązku ubezpieczenia zdrowotnego - zarówno nakładanego na większych pracodawców, jak i indywidualnych obywateli. Sprawa jest traktowana przez republikanów jako prestiżowa i kierownictwo tej partii jest zdeterminowane, by zrealizować swoje obietnice wyborcze. Oficjalny program Partii Republikańskiej w stosunku do Obamacare to ,zniesienie i zastąpienie" (repeal and replace) [27-29].

Istotnym kontekstem do omawianych reform jest rosnąca systematycznie od czasu prezydentury Obamy polaryzacja polityczna i ideologizacja sceny politycznej w USA. Tradycja amerykańskiej polityki, czyli uchwalanie reform, dla których poparcie udało się zdobyć po obu stronach podziału partyjnego (bipartisanship), staje się coraz wyraźniej przeszłością [30]. Dobitnym tego przykładem było samo uchwalenie ustawy fundującej Obamacare (ACA). Spotkała się ona $\mathrm{z}$ bezwzględnym oporem ze strony republikanów mimo prób włączenia ich w jej tworzenie, a także pomimo tego, że reforma ta wzorowana była na dość zachowawczej reformie zdrowotnej wprowadzonej w stanie Massachusetts (tak zwanej Romneycare), gdy jego gubernatorem był Mitt Romney, późniejszy rywal Obamy w wyborach prezydenckich [31]. Sytuacja ta oznacza, że w aktualnym klimacie politycznym - szczególnie po nadzwyczaj antagonistycznej kampanii prezydenckiej roku 2016 - proponowana Trumpcare nie ma szans na zdobycie istotnego (jeśli w ogóle) poparcia ze strony demokratów. Nie pomagają w tym sami republikanie, którzy w bezprecedensowy sposób odcinają demokratów od możliwości współkształtowania w komisjach rzeczonego projektu ${ }^{6}$. Polaryzacja ujawnia się także wśród elektoratu członków kongresu.
Podobnie jak w przypadku wprowadzania Obamacare [33] tradycyjne amerykańskie Town Halls - czyli regularne spotkania senatorów z mieszkańcami ich okręgów wyborczych w celu omawiania polityk - stają się areną bardzo żywiołowej aktywności politycznej. Tym razem niskie poparcie społeczne dla planu zniesienia Obamacare [34] i silna mobilizacja polityczna zwolenników jej utrzymania sprawiają, że republikańscy senatorowie mają problem $\mathrm{z}$ uzasadnieniem polityki swojej partii wobec wyborców [35] do tego stopnia, że następuje ograniczenie frekwencji przeprowadzania wspomnianych Town Halls [36].

W początkach urzędowania prezydenta Donalda Trumpa republikanie w kongresie po raz pierwszy usiłowali przeprowadzić swoje reformy zdrowotne w marcu 2017 roku. Jednak projekt pilotowany przez Paula Ryana [37] - republikańskiego spikera Izby Reprezentantów został wycofany. Przyczyną były wątpliwości, czy uda się go uchwalić nawet przez samych republikanów. Już na tym etapie w obozie partii rządzącej ujawniły się silne podziały ideowe. Niektórzy kongresmeni sprzeciwiali się proponowanym zmianom, dlatego że były zbyt surowe $\mathrm{w}$ redukcji zabezpieczenia dla najbardziej potrzebujących. Inni odwrotnie: kongresmeni należący do tak zwanej Freedom Caucus (dosłownie „kliki wolności”) byli nieusatysfakcjonowani projektem, dlatego że był on za mało kategoryczny w redukcji podatków i wsparcia z Medicaid. Sytuacja powtórzyła się w senacie w kontekście najnowszego projektu, który udało się przegłosować w Izbie Reprezentantów. Aktualnie sześciu republikańskich senatorów uważa cięcia w Medicaid za zbyt daleko posunięte, natomiast dwóch chce, by były większe; trzech chce utrzymania pełni obowiązków ubezpieczania, podczas gdy czterech chce jeszcze większej liberalizacji; czterech chce łagodniejszego ograniczenia podatków $\mathrm{w}$ ramach Obamacare, $\mathrm{z}$ kolei czterech chce ich jeszcze silniejszego ograniczenia; wreszcie dwóch senatorów chce utrzymania finansowania Planned Parenthood (Planowane Rodzicielstwo) [38].

\section{Trumpcare w hudowie}

Republikański projekt zastąpienia Obamacare, czyli Trumpcare, zawiera wiele rozwiązań wprost odnoszących się do istotnych zapisów Obamacare. Na ten moment Trumpcare występuje w dwóch, nieco odmiennych wersjach: uchwalonej przez Izbę Reprezentantów i właśnie opracowywanej w senacie (zaprezentowanej 22 czerwca 2017 roku).

Oba projekty znoszą obowiązek ubezpieczenia zdrowotnego. Według szacunków likwidacja podatków (,kar”) za indywidualny brak ubezpieczenia doprowadzi 14 milionów osób do rezygnacji z ubezpieczenia [39]. To, razem z likwidacją podatków (,kar”) nałożonych na firmy niezapewniające ubezpieczenia swoim pracownikom, ma doprowadzić, według oczekiwań, do podniesienia kosztów ubezpieczenia zdrowotnego. Oba projekty republikanów znoszą wysokie podatki dla firm farmaceutycznych i producentów sprzętu medycznego, zachowując opodatkowanie wyższej klasy programów ubezpieczeniowych 
(,Cadillac” insurance plans); a także likwiduja podatki dla najbogatszych (dochód roczny powyżej 200000 USD). Pakiet obowiązkowych świadczeń podstawowych (porody, choroby przewlekłe itp.) ma nie być ustalany na poziomie federalnym, a uzależniony będzie od decyzji poszczególnych stanów [40]. Indywidualne Konta Oszczędności Zdrowotnych (Health Savings Accounts), przewidziane dla ubezpieczonych z najwyższymi składkami, według nowej reformy mają być dostępne dla wszystkich. Dotychczasowy limit na wysokość składek zdrowotnych dla osób starszych zostanie podniesiony z trzykrotności do pięciokrotności kosztów dla osób młodszych. Natomiast popularny zapis Obamacare dający dzieciom do 26. roku życia możliwość korzystania z ubezpieczenia rodziców zostanie zachowany.

Występują tu jednak także pewne różnice [41]. Oba projekty redukują dofinansowanie rozszerzenia Medicaid
- plan senacki w większym zakresie, ale po dłuższym vacatio legis (dopiero od 2021 roku) niż w wersji Izby Reprezentantów [42]. Plany republikanów różnią się także sposobem wyznaczania subsydiów do ubezpieczeń: izby oparty jest na wieku, podczas gdy wersja senacka bazuje na dochodzie. Istotną kwestią jest regulacja możliwości odmowy przez HMO ubezpieczenia osób z „uprzednio występującymi stanami (nie)zdrowia” (pre-existing conditions). $\mathrm{O}$ ile wersja Izby Reprezentantów pozostawi regulację tego w kwestii stanów, senacki projekt podtrzymuje zakaz obecny w Obamacare. Politycznie drażliwą sprawą jest finansowanie w ramach Medicaid świadczeń zdrowia reprodukcyjnego świadczonych przez organizację Planned Parenthood. Projekt izby znosi finansowanie całkowicie, podczas gdy senacki znosi je tylko na rok [43-44]. Porównanie najważniejszych zmian przedstawia Tabela V.

\begin{tabular}{|c|c|c|c|}
\hline & \multirow[t]{2}{*}{ OBAMACARE (ACA) } & \multicolumn{2}{|c|}{ Projekt: TRUMPCARE (AHCA) } \\
\hline & & $\begin{array}{l}\text { Izba Reprezentantów } \\
\text { [uchwalony] }\end{array}$ & $\begin{array}{l}\text { Senat } \\
\text { [w pracach] }\end{array}$ \\
\hline $\begin{array}{l}\text { „Obowiązek” ubezpieczeniowy: } \\
\text { indywidualny (właściwe opodat- } \\
\text { kowanie nieubezpieczenia) i dla } \\
\text { firm zatrudniających powyżej } 50 \\
\text { pracowników }\end{array}$ & Tak & Zniesiony & $\begin{array}{l}\text { Zniesiony } \\
\text { [3 senatorów chce utrzymania } \\
\text { obowiązków ubezpieczania, } \\
4 \text { chce jeszcze większej libera- } \\
\text { lizacji] }\end{array}$ \\
\hline $\begin{array}{l}\text { Podatki na firmy medyczne i zamoż- } \\
\text { nych itp. }\end{array}$ & Tak & Zniesiony & $\begin{array}{l}\text { Zniesiony } \\
\text { [4 senatorów chce utrzymania, } \\
4 \text { chce ich jeszcze silniejszego } \\
\text { ograniczenia] }\end{array}$ \\
\hline $\begin{array}{l}\text { Podatki dla najbogatszych (dochody } \\
\text { powyżej } 200000 \text { USD rocznie) }\end{array}$ & Tak & $\begin{array}{l}\text { Zniesione } \\
\text { [6 lat vacatio legis] }\end{array}$ & Zniesione \\
\hline $\begin{array}{l}10 \text { podstawowych świadczeń } \\
\text { zdrowotnych }\end{array}$ & Obowiązkowe & Zależne od stanu & Zależne od stanu \\
\hline Medicaid & $\begin{array}{l}\text { Rozszerzenie (po wyroku Sądu } \\
\text { Najwyższego: fakultatywne dla } \\
\text { stanów) }\end{array}$ & Ograniczenia & $\begin{array}{l}\text { Poważniejsze ograniczenia, ale } \\
\text { w dłuższym okresie } \\
\text { [6 senatorów uważa za zbyt } \\
\text { surowe, } 2 \text { za zbyt łagodne] }\end{array}$ \\
\hline Subsydia i ulgi podatkowe & $\begin{array}{l}\text { Kalkulowane według dochodu } \\
\text { i kosztu ubezpieczenia; dotyczą } \\
\text { również współpłacenia }\end{array}$ & $\begin{array}{l}\text { Kalkulowane według wieku; } \\
\text { nie dotyczą współpłacenia oraz } \\
\text { aborcji }\end{array}$ & $\begin{array}{l}\text { Kalkulowane według dochodu; } \\
\text { nie dotyczą współpłacenia oraz } \\
\text { aborcji }\end{array}$ \\
\hline $\begin{array}{l}\text { Odmowa ubezpieczenia ze względu } \\
\text { na uprzednio występujące stany (nie) } \\
\text { zdrowia (pre-existing conditions) }\end{array}$ & Zakaz & Możliwa zależnie od stanu & Zakaz \\
\hline $\begin{array}{l}\text { Finansowanie świadczeń zdrowia } \\
\text { reprodukcyjnego (Planned } \mathrm{Pa} \text { - } \\
\text { renthood) }\end{array}$ & $\begin{array}{l}\text { Refundacja w ramach Medicaid } \\
\text { poza aborcją }\end{array}$ & Zniesienie finansowania & $\begin{array}{l}\text { Zniesienie finansowania na rok } \\
\text { [2 senatorów chce utrzymania] }\end{array}$ \\
\hline $\begin{array}{l}\text { Konta Oszczędności Zdrowotnych } \\
\text { (Health Savings Accounts) - wy- } \\
\text { korzystywane przy wyczerpaniu } \\
\text { limitów świadczeń }\end{array}$ & $\begin{array}{l}\text { Tylko dla najdroższych planów } \\
\text { zdrowotnych }\end{array}$ & Dla wszystkich & Dla wszystkich \\
\hline $\begin{array}{l}\text { Limity na składki dla osób starszych } \\
\text { w stosunku do młodszych }\end{array}$ & Maksymalnie 3 razy & Maksymalnie 5 razy & Maksymalnie 5 razy \\
\hline $\begin{array}{l}\text { Korzystanie z planu ubezpieczenio- } \\
\text { wego rodziców do } 26 \text {. roku życia }\end{array}$ & Tak & Zachowany & Zachowany \\
\hline
\end{tabular}

Tabela V. Porównanie najważniejszych zmian Obamacare a Trumpcare (w dwóch wersjach izb kongresu).

Źródło: Opracowanie na podstawie Amadeo K., Donald Trump on Health Care. Trumpcare vs Obamacare: Which Is Better for You?, ,, US Economy”, 22.06.2017, https://www.thebalance.com/how-could-trump-change-health-care-in-america-4111422 [41]. 


\section{Oczekiwane konsekwencje}

Do oczekiwanych skutków reformy należy obniżenie podatków dla najbogatszych i wielu kategorii przedsiębiorstw, w tym firm farmaceutycznych i producentów sprzętu medycznego. Spodziewane jest też obniżenie kosztów pracy dla pracodawców w wyniku likwidacji „obowiązku” ubezpieczenia swoich pracowników. Potencjalnie mniejsze koszty ponosić będą także osoby zdrowe i młode.

W wyniku rezygnacji wielu mieszkańców z udziału w ubezpieczeniu, a zarazem przy zachowaniu zakazu odmowy ubezpieczenia osób z uprzednim stanem niezdrowia - koszty ubezpieczeń będą rosnąć znacznie szybciej, niż miało to miejsce podczas obowiązywania Obamacare (1\% miesięcznie; przed wprowadzeniem Obamacare koszty rosły o 3\% miesięcznie). Te osoby, które zachowają ubezpieczenie, stracą znaczny zakres świadczeń gwarantowanych i mogą stanąć w obliczu wprowadzenia przez ubezpieczycieli limitów na świadczenia [45]. Dla osób z chorobami chronicznymi koszty ubezpieczenia będą znaczne. Z kolei osoby, które kwalifikowały się do rozszerzenia Medicaid, ponownie „wypadną” z systemu, pozostawiając niższe warstwy klasy średniej w istotnym ryzyku braku realnego dostępu do opieki zdrowotnej lub ryzyku bankructwa konsumenckiego spowodowanego kosztami leczenia.

Istnieje obawa, że z perspektywy budżetowej cięcia w Obamacare nie wynagrodzą wprowadzanych redukcji podatków [46]. W przypadku stwierdzenia tego przez Kongresowe Biuro Obrachunkowe republikanie nie będą w stanie całkowicie zlikwidować Obamacare, jako że Trumpcare $\mathrm{w}$ przedstawionym kształcie powodowałby zwiększenie długu publicznego w ciągu najbliższych 10 lat, a to wymaga większości 60 senatorów, której nie mają. W związku z tym proponowane reformy mogą mieć jedynie charakter obezwładnienia obowiązującej ACA. Formalnie zachowany będzie „obowiązek” ubezpieczenia, ale opodatkowanie takiego obowiązku zostanie zredukowanie do zera.

\section{Podsumowanie}

Trump, podobnie jak Obama, Clinton i inni prezydenci przed nim, podjął próbę naprawy systemu ochrony zdrowia w USA. Sam prezydent i sprzyjający mu republikańscy legislatorzy przekonują do reformy. Niestety, jak to bywało wcześniej, tak i teraz dyskusja o reformie zdrowotnej wzbudza wiele emocji, burzliwych protestów przeciw rządowemu planowi i całej polityce Trumpa. Sami republikanie są podzieleni i nie popierają w sposób jednomyślny i pełny nowych projektów zmian w systemie zdrowotnym.

Poprzednia zmiana - Affordable Care Act (ACA) została uchwalona przez Kongres w 2010 roku głosami demokratów. Przyniosła ona w polityce zdrowotnej USA najistotniejsze zmiany od czasu utworzenia w 1965 roku programów dla seniorów Medicare i ludzi ubogich Medicaid. ACA ułatwił nabywanie prywatnych planów ubezpieczeń zdrowotnych osobom, które nie miały zagwarantowanego dostępu do tego rodzaju usług przez pracodawców. Rozszerzył też świadczenia Medicaid w około trzech piątych amerykańskich stanów. Ponadto ustawa sprawiła, że firmy ubezpieczeniowe nie mogą, tak jak dawniej, odmawiać usług osobom, które już wcześniej nabawiły się poważnych schorzeń lub cierpią na choroby wrodzone.

Porównując obecną sytuację osób nieubezpieczonych z tą sprzed reformy, można stwierdzić, że na skutek rosnących składek (i relatywnie wyższego poziomu współpłacenia niż przed reformą) nie uległa ona, niestety, zasadniczej poprawie. Idea ubezpieczenia polega na pewnym solidaryzmie, który w warunkach ukształtowanych przez Obamacare bardzo trudno było osiągnąć. Na podstawie oceny obecnej sytuacji w amerykańskiej polityce sektorowej można oczekiwać zmian w dwóch kierunkach. W pierwszym przypadku wprowadzone regulacje można cofnąć i tym samym umożliwić ubezpieczycielom odpowiednią selekcję ryzyka. Wycofanie Obamacare wiąże się także dla osób wciąż ubezpieczonych niewątpliwie z utratą ulg podatkowych i innych subwencji. Należy jednak pamiętać, że Obamacare staje się coraz bardziej kosztowna: dla ubezpieczonych, państwa, czyli podatników, a także firm ubezpieczeniowych [47].

Propozycje Donalda Trumpa mogą mieć implikacje głównie ubezpieczeniowe, ale też rynkowe, ponieważ ograniczenie dostępu do publicznych usług medycznych może też negatywne wpłynąć na niektórych dostawców usług związanych z opieką zdrowotną oraz producentów wyrobów medycznych. $Z$ kolei wielu producentów leków od kilku miesięcy odczuwało wzmożoną presję związaną z rynkowymi obawami, że administracja Hillary Clinton mogłaby podjąć legislacyjne działania na rzecz racjonalizacji cen leków, co niekorzystnie wpłynęłoby na przedsiębiorstwa farmaceutyczne i biotechnologiczne.

Środowisko jest bardzo podzielone w ocenie Obamacare i nowych propozycji prezydenta Trumpa. Nowa zmiana jest wspierana przez korporacje ubezpieczeniowe. Tymczasem największe amerykańskie stowarzyszenie lekarzy, American Medical Association, wysłało do liderów obu partii w senacie list $\mathrm{z}$ oświadczeniem, w którym podkreśla, że poparło Obamacare, ponieważ stanowiła znaczącą poprawę w stosunku do poprzedniego status quo. Wezwało też kongres, by wstrzymał się z uchyleniem Obamacare do czasu wprowadzenia nowych zasad polityki zdrowotnej. Prezes Krajowego Partnerstwa na rzecz Kobiet i Rodziny Debra L. Ness oświadczyła, że uchylenie ustawy Obamacare zniweczy to, co było największym postępem w opiece zdrowotnej dla kobiet od pokoleń [48].

\section{Przypisy}

${ }^{1}$ Polityka aborcyjna jest różna w poszczególnych stanach, stąd zapis ten został dostosowany do obowiązujących przepisów.

2 Strona ta działa pod adresem Healthcare.gov.

3 Jest to program zawierający m.in. leczenie cukrzycy, pomoc w rzuceniu palenia tytoniu, pomoc w odchudzaniu i profilaktyczne badania zdrowotne. 
${ }^{4}$ Według ACA jest pobierana ,tak jak” i ,razem z” innymi podatkami indywidualnymi.

${ }^{5} \mathrm{~W}$ momencie wejścia $\mathrm{w}$ życie tej regulacji minimalna kara wynosiła tylko 95 USD.

${ }^{6} \mathrm{Na}$ problem ten wskazała demokratyczna senator Claire McCaskill w wystąpieniu opublikowanym na portalu społecznościowym Facebook [32].

\section{Piśmiennictwo}

1. Tandom A., Murray C.J., Lauer J.A., Evans D.B., Measuring Overall Health System Performance for 191 Countries, GPE Discussion Paper Series: No. 30, EIP/GPE/ EQC World Health Organization, 2000, http://www.who. int/healthinfo/paper30.pdf (dostęp: 10.07.2017).

2. Włodarczyk C., Reformy zdrowotne - uniwersalny ktopot, Wydawnictwo Uniwersytetu Jagiellońskiego, Kraków 2003.

3. Amadeo K., The Ultimate Obamacare Handbook (20152016 edition): A Definitive Guide to the Benefits, Rights, Responsibilities, and Potential Pitfalls of the Affordable Care Act, Skyhorse Publishing 2016.

4. OECD, Health at a Glance 2015: OECD Indicators, OECD Publishing, Paris 2015, http://dx.doi.org/10.1787/health glance-2015-en (dostęp: 10.07.2017).

5. Levy J., In U.S., Uninsured Rate Lowest Since 2008, „Gallup WellBeing” 2014, http://www.gallup.com/poll/168248/ uninsured-rate-lowest-2008.aspx (dostęp: 10.07.2017).

6. Nolte E., McKee M., Measuring the Health of Nations: Updating an earlier analysis, ,Health Affairs” 2008; 27, 1: 58-71.

7. OECD, Health at a Glance 2013: OECD Indicators, OECD Publishing, 2013, http://dx.doi.org/10.1787/health_glance-2013-en (dostęp: 10.07.2017).

8. Zabdyr-Jamróz M., Badora K., Reformy zdrowotne w USA z 2010 r. po orzeczeniu Sądu Najwyższego. Europeizacja Ameryki czy utrzymanie jej odrębności?, w: Namysty nad problemami polityki zdrowotnej globalnej - europejskiej - krajowej: ksiega jubileuszowa prof. dra hab. Cezarego W. Włodarczyka, red. nauk. I. Kowalska, A. Mokrzycka, Difin, Warszawa 2013: 241-255.

9. Makowska M., Czerw A., Reforma systemu ubezpieczeń zdrowotnych $w$ Stanach Zjednoczonych. Zmiany wprowadzane przez Obamacare, „Hygeia Public Health” 2014; 49 (4): 733-741.

10. KFF, 2013 employer health benefits survey, The Henry J. Kaiser Family Foundation, October 2013, http://kff.org/private-insurance/report/2013-employer-health-benefits (dostęp: 10.07.2017).

11. KFF, Employer Health Benefits. 2013 Summary of Findings, The Henry J. Kaiser Family Foundation, 2013, https://kaiserfamilyfoundation.files.wordpress.com/2013/08/8466-employer-health-benefits-2013_summary-of-findings 1.pdf (dostęp: 10.07.2017).

12. eHalth, Cost and Benefits of Individual and Family Health Insurance, 2013, http://news.ehealthinsurance.com/_ ir/68/201311/eHealth\%202013\%20Cost\%20and\%20Benefits\%20Report.pdf (dostęp: 10.07.2017).

13. Jasiński Ł., Makowska M., Wplyw reformy zdrowotnej w Stanach Zjednoczonych (ObamaCare) na biznes ubez- pieczeniowy, „Wroclaw Economic Review” 2016; 22 (2): 9-25.

14. IRS, Internal Revenue Bulletin: 2017-21, 2017, https:// www.irs.gov/irb/2017-21_IRB/ar10.html\#d0e870 (dostęp: 10.07.2017).

15. KFF, Obamacare and You: If You Are a Woman..., The Henry J. Kaiser Family Foundation, October 2013, http:// www.kff.org/health-reform/fact-sheet/obamacare-and-you-if-you-are-a-woman/ (dostęp: 10.07.2017).

16. Obamacare Facts, ObamaCare Employer Mandate, https:// obamacarefacts.com/obamacare-employer-mandate/ (dostęp: 10.07.2017).

17. Healthcare, Medicaid expansion \& what it means for you, https://www.healthcare.gov/medicaid-chip/medicaid-expansion-and-you/ (dostęp: 10.07.2017).

18. KFF, The YouToons Get Ready for Obamacare: Health Insurance Changes Coming Your Way Under the Affordable Care Act, The Henry J. Kaiser Family Foundation, July 2013, http:/www.kff.org/health-reform/video/youtoons-obamacare-video/ (dostęp: 10.07.2017).

19. Niżnik J., Reforma modelu ochrony zdrowia $w$ Stanach Zjednoczonych: nowe zasady finansowania a dostepność opieki zdrowotnej, „Annales Universitatis Mariae Curie-Skłodowska. Sectio H. Oeconomia” 2010; 44 (2): 981-993.

20. Makowska M., Jasiński Ł., Wplyw reformy zdrowotnej w Stanach Zjednoczonych (ObamaCare) na biznes farmaceutyczny, „Wroclaw Economic Review” 2016; 22 (4): 35-46.

21. HHS, Health Plan Choice and Premiums in the 2017 Health Insurance Marketplace, Department of Health and Human Services, October 2016, https://aspe.hhs.gov/system/files/ pdf/212721/2017MarketplaceLandscapeBrief.pdf (dostęp: 10.07.2017).

22. PAF, Health Reform and You. A User's Guide to the Health Insurance Marketplace, Patient Advocate Foundation, http:// www.patientadvocate.org/requests/publications/Health-Reform-and-You.pdf (dostęp: 10.07.2017).

23. Novo Nordisk, Understanding health insurance. Your reference guide, September 2016, https://www.cornerstones4care.com/content/dam/nni/cornerstones4care/pdf/others/ Health_Insurance_Booklet.pdf (dostęp: 10.07.2017).

24. KFF, Obamacare and You: If You Are Uninsured..., The Henry J. Kaiser Family Foundation, October 2013, http://www. kff.org/health-reform/fact-sheet/obamacare-you-if-you-are-uninsured/ (dostęp: 10.07.2017).

25. Jackson H.C., 6 promises Trump has made about health care, „Politico”, 13.03.2017, http://www.politico.com/story/2017/03/trump-obamacare-promises-236021 (dostęp: 10.07.2017).

26. Sarlin B., Trump's Backing a Healthcare Plan That Breaks His Promises, CNBC, 13.03.2017, http://www.cnbc. com/2017/03/13/trumps-backing-a-healthcare-plan-that-breaks-his-promises.html (dostęp: 10.07.2017).

27. AHCA, Our time is now, The American Health Care Act, https://housegop.leadpages.co/healthcare/ (dostęp: 10.07.2017).

28. Trumpcare, Trump's Mysterious "Repeal and Replace" Plan, Health Network Group 2017, https://trumpcare. com/trumps-mysterious-repeal-and-replace-plan (dostęp: 10.07.2017). 
29. Kamisar B., Trump: 'ObamaCare is dead', „The Hill”, 17.03.2017, http://thehill.com/policy/healthcare/324453-trump-obamacare-is-dead (dostęp: 10.07.2017).

30. PRC, Political Polarization in the American Public, Pew Research Center for the People and the Press, June 2014, http://www.people-press.org/2014/06/12/political-polarization-in-the-american-public/ (dostęp: 10.07.2017).

31. Diffen, Obamacare vs. Romneycare, http://www.diffen. com/difference/Obamacare_vs_Romneycare (dostęp: 10.07.2017).

32. U.S. Senate Democrats (2017), Will there be a hearing on the Healthcare proposal?, Facebook, 09.06.2017, https:// www.facebook.com/USSenateDemocrats/videos/13560830 $14460889 /$ ?autoplay_reason=gatekeeper\&video_container type $=0 \&$ video_creator_product_type $=2 \&$ app_id $=2392950$ 137\&live_video_guests $=0$ (dostęp: 10.07.2017).

33. Menkel-Meadow C., Scaling up deliberative democracy as dispute resolution in healthcare reform: A work in progress, „Law and Contemporary Problems” 2011; 74 (3): 1-30.

34. Bryan B., The Republican healthcare bill is the least popular major bill in decades, „Business Insider”, 21.06.2017, http:// www.businessinsider.com/poll-ahca-obamacare-approval-ratings-2017-6? IR=T (dostęp: 10.07.2017).

35. Yglesias M., The massive wave of town hall protests ruining the GOP's week, explained, „Vox”, 23.02.2017, https://www. vox.com/policy-and-politics/2017/2/23/14696472/town-hall-protests (dostęp: 10.07.2017).

36. Stein J., Republicans don't hold town halls anymore, „Vox”, 27.06.2017, https://www.vox.com/policy-and-politics/2017/6/27/15880904/republicans-town-hall-health-care (dostęp: 10.07.2017).

37. Trumpcare, Comparison of Trumpcare Plans, Health Network Group, 2017, https://trumpcare.com/comparison-trumpcare-plans (dostęp: 10.07.2017).

38. Scott D., The Senate GOP's health care stalemate, in one chart, ,Vox”, 03.07.2017, https://www.vox.com/policy-and-politics/2017/7/3/15905512/senate-health-care-bill-mitch-mcconnell-one-chart (dostęp: 10.07.2017).

39. CBO, American Health Care Act. Budget Reconciliation Recommendations of the House Committees on Ways and Means and Energy and Commerce, The Congressional Budget Office, 09.03.2017, https://www.cbo.gov/system/ files/115th-congress-2017-2018/costestimate/americanhealthcareact.pdf (dostęp: 10.07.2017)

40. Anderson T., Senate's Obamacare Replacement Bill to Boost Health Savings Accounts, CNBC, 22.06.2017, http://www. cnbc.com/2017/06/22/senate-obamacare-replacement-to-boost-health-savings-accounts.html (dostęp: 10.07.2017).

41. Amadeo K., Donald Trump on Health Care. Trumpcare vs Obamacare: Which Is Better for You?, „US Economy”, 22.06.2017, https://www.thebalance.com/how-could-trump-change-health-care-in-america-4111422 (dostęp: 10.07.2017).

42. Pear R., What's in the AHCA: The Major Provisions of the Republican Health Bill, „The New York Times”, 04.05.2017, https://www.nytimes.com/2017/05/04/us/ politics/major-provisions-republican-health-care-bill.html (dostęp: 10.07.2017).

43. Crockett E., The GOP Obamacare Replacement Plan Defunds Planned Parenthood and Restricts Abortion
Coverage, „Vox”, 07.03.2017, https://www.vox.com/ identities/2017/3/6/14836998/obamacare-repeal-replace-bill-defund-planned-parenthood (dostęp: 10.07.2017).

44. Winfield Cunningham P., Here's What's in the Senate Health Care Bill, „The Washington Post”, 22.06.2017, https:// www.washingtonpost.com/news/powerpost/paloma/the-health-202/2017/06/22/the-health-202-here-s-what-s-in-the-senate-health-care-bill/594aa367e9b69b2fb981dde9/? utm_term=.13a89cd6b4fb (dostęp: 10.07.2017).

45. Armour S., Hackman M., GOP Health Bill Jeopardizes Out-of-Pocket Caps in Employer Plans, „The Wall Street Journal”, 04.05.2017, https://www.wsj.com/articles/little-noted-provision-of-gop-health-bill-could-alter-employer-plans-1493890203 (dostęp: 10.07.2017).

46. Goodnough A., Pear R., Kaplan T., Health Groups Denounce G.O.P. Bill as Its Backers Scramble, „New York Times”, 09.03.2017, https://www.nytimes.com/2017/03/08/us/politics/affordable-care-act-obama-care-health.html (dostęp: 10.07.2017).

47. Obamacare vs. Trumpcare (BCRA), 16.09.2017, https:// trumpcare.com/trumpcare-vs-obamacare (dostęp: 10.07. 2017).

48. Business Insider Polska, Likwidacja Obamacare pozbawi miliony Amerykanów opieki lekarskiej. Stracić moga też inwestorzy, „Business Insider Polska”, 05.01.2017, http://businessinsider.com.pl/wiadomosci/reforma-opieki-zdrowotnej-w-usa-likwidacja-obamacare-konsekwencje/ gvmtqbb (dostęp: 16.09.2017).

49. Rice T., Rosenau P., Unruh L.Y., Barnes A.J., Saltman R.B., van Ginneken E., United States of America: Health system review, „Health Systems in Transition” 2013; 15 (3): 1-431.

50. KFF, Medicare a Primer 2010, The Henry J. Kaiser Family Foundation, April 2010, http://www.kff.org/medicare/upload/7615-03.pdf (dostęp: 10.07.2017).

51. Baumgartner E., Emerytura polska i amerykańska ich łaczenie i skutki Umowy o zabezpieczeniu społecznym, Polpress Services, Nowy Jork, „Ameryka dla każdego” 2015, https:// poradniksukces.com/wp/wp-content/uploads/2016/04/Emerytura_polska_i_am_ebook_2015.pdf(dostęp: 10.07.2017).

52. CMS, Medicare Basics: A Guide for Families and Friends of People with Medicare, The Centers for Medicare and Medicaid Services Product No. 11034, 2014, https://www.medicare.gov/Pubs/pdf/11034.pdf (dostęp: 10.07.2017).

53. CMS, Czym jest Medicare?, The Centers for Medicare and Medicaid Services Product No. 11306 - Polish, 2015, https://www.medicare.gov/pubs/pdf/other-languages-not-sp/Polish\%2011306-Medicare-Medicaid.pdf (dostęp: 10.07.2017).

54. CMS, Medicare and You 2017, The Centers for Medicare and Medicaid Services Product No. 10050, 2016, https:// www.medicare.gov/pubs/pdf/10050-Medicare-and-You.pdf (dostęp: 10.07.2017).

55. Snyder L., Rudowitz R., Ellis E., Roberts D., Medicaid Enrollment: June 2013 Data Snapshot, Kaiser Family Foundation, Washington, DC 2014, http://kff.org/medicaid/ issue-brief/medicaidenrollment-june-2013-data-snapshot/ (dostęp: 10.07.2017).

56. eHalth, The Different Types of Health Insurance Plans, 2016, https://resources.ehealthinsurance.com/individual-and-family/different-types-health-insurance-plans (dostęp: 10.07.2017). 
57. CFF, The Insurance Basics, Cystic Fibrosis Foundation, https://www.cff.org/Assistance-Services/Insurance/Your-Insurance-Plan/The-Insurance-Basics/ (dostęp: 10.07.2017).

58. ACS, Types of Health Insurance Plans, American Cancer Society, 2016, https://www.cancer.org/treatment/finding-and-paying-for-treatment/understanding-health-insurance/health-insurance-options/types-of-health-insurance-plans.html (dostęp: 10.07.2017).
59. Blue Cross and Blue Shield of Illinois, Understanding Health Insurance. Your Guide to the Affordable Care Act, https://www.bcbsil.com/pdf/standards/understanding_health_insurance_member_brochure.pdf (dostęp: 10.07.2017).

60. CAHP, 7 Ways the Affordable Care Act will Impact Individual Health Insurance, California Association of Health Plans, http://www.calhealthplans.org/pdfs/ACAImpactInfographicMultiplePages042913.pdf (dostęp: 10.07.2017). 